\title{
More than Politics: Forces Affecting Media Freedom in Mainland China, Hong Kong and Taiwan
}

\author{
Zhongxuan Dai \\ School of Communication, Hong Kong Baptist University, Hong Kong, China \\ Email: 15484483@life.hkbu.edu.hk
}

How to cite this paper: Dai, Z. X. (2018). More than Politics: Forces Affecting Media Freedom in Mainland China, Hong Kong and Taiwan. Advances in Journalism and Communication, 6, 19-25. https://doi.org/10.4236/ajc.2018.61002

Received: January 30, 2018

Accepted: March 26, 2018

Published: March 29, 2018

Copyright $\odot 2018$ by author and Scientific Research Publishing Inc. This work is licensed under the Creative Commons Attribution International License (CC BY 4.0).

http://creativecommons.org/licenses/by/4.0/

\section{c) (i) Open Access}

\begin{abstract}
This essay has compared difference in media freedom that journalists share in mainland China, Hong Kong and Taiwan and has discussed the reasons behind such a difference on three levels. Despite of the obvious political and economic forces on societal level, the author has also explored psychological forces on individual level and cultural forces on organizational level. As important as the political background is, it should not be used as a master key to solve every case regarding these regions. Thus, the author intends to call upon attention to forces on the other two levels as well, since the real battle is not just about breaking free from external political or economic forces, but also about breaking free from internal forces, about dealing with psychological and cultural forces leading them unconsciously every day. Also, this is a critical essay instead of an empirical quantitative study, so the discussions would largely remain theoretical. However, by pointing out the theoretical gap, the discussion may shed light upon directions of future empirical studies as further explorations.
\end{abstract}

\section{Keywords}

Media Freedom, Authoritarian Character, Organizational Culture, Political Backgrounds

\section{Introduction}

To know how much freedom a journalist may enjoy, region is always taken into consideration. As the World Press Freedom Index spotlights, different regions share different freedom across the world. An interesting contrast is found among China, Hong Kong and Taiwan, with the rank of 176, 73 and 45 (rsf.org, 
2017). These three societies are generally using the same language, having close geographical proximity, thus such a stark contrast provides a unique context for studying the factors behind. Usually such contrasts are studied in political context, discussing the relations between media and political powers (Hallin \& Mancini, 2004). Scholars also use ideological controls to explain such differences in journalism freedom and take Mainland China, Hong Kong each as a not free, a partly free and a free media system (Du \& Cheng, 2013).

It is true that politics play an important part in this process and is a great factor when it comes to journalism freedom, but such an outcome is caused by more than politics. It's also about psychology, history and culture, thus the factors should be examined from more than one dimension.

\section{Forces on Different Levels}

The freedom a journalist may enjoy is highly related with media decision making process, which could be examined on 3 levels: personal level, organizational level and social level. When talking about political or economic forces against media freedom, such conflicts are basically discussed on a social level, considering all media organizations as a whole. However, during actual practices, such conflicts may possibly take place on personal and organizational levels as well. Therefore, when examining forces affecting a journalist's choice and freedom, different levels may lead to very different approaches.

\section{Personal Level: Freedom to or Free from? A Psychological Approach}

When a journalist thinks about which topic to report to his/her editor, during the process nobody interferes him/her. All possible conflicts remain internal, which could be further explored via psychological approaches. Comparatively rare studies have compared journalistic practices from these three regions through rather personal lens, but efforts could be found such as Yang and Arant's (2014) study focusing how journalists from these regions' perceptions and attitudes would differ according to conflicts of interests including taking freebies or gifts. Deeper reasons lie behind such different perceptions.

Synthesizing psychology and a critical perspective on modern social forces, Fromm has once pointed out that modern industrial systems tend to cultivate an authoritarian character in people, making them feel powerless and alone, anxious and insecure, and thus tend to submit to higher powers (Fromm, 1942).

Fromm distinguishes between freedom from, which refers to emancipation from restrictions such as social conventions placed on individuals by other people or institutions, and freedom to, which is used to employ the total integrated personality in creative acts.

Now decades have passed, these themes may no longer suitable for describing well-developed regions such as Hong Kong or Taiwan, where the societies are already modern enough, heading towards post-modernism. However, when it 
comes to Mainland China, such themes could still be to some degree insightful. The economy of Mainland China has been soaring for the last 30 years. Up to now, the social situation shares many similarities with the early stages of capitalist development in western history.

Consequently, compared to Hong Kong or Taiwan, it's more likely for mainland people (including journalists) to form an authoritarian character, which not only contributes to self-censorships when choosing a topic, but also, more importantly, contributes to choosing politically right topics unconsciously even without self-censorship. Such a suppression is similar to a description of women in patriarchy society: "they participated in the process of their own subordination because they have been psychologically shaped so as to internalize the idea of their own inferiority" (O’Connor \& Drury, 1999).

\section{Organizational Level: Communism, Britain and Confucianism, A Cultural Approach}

After a journalist report a topic to his/her editor, there could be possible conflicts between the two of them, or between them and other people in the organization. In either case, possible conflicts are on organizational level. Some previous studies have noticed the difference on organizational level from these three societies, such as how travel agency management system could differ (Wen \& Hou, 2015). Some have compared such a difference from a cultural perspective, such as how leaders in Hong Kong, Taiwan and China would have different preference in their influence tactics the different degrees of Confucianism's impact on these three societies (Fu et al., 2004). However, rare attention has been particularly given to news organizations, while it is true that different cultures would lead to different outcomes when it comes to conflicts on organizational level. The following part intends to fill the gap and compare news organizations from these three regions with a cultural approach via Hofstede's theory. Although Hofstede's Dimensions has received some critiques (Fang, 2003), this model is still very useful when measuring different cultures (Preda, 2012).

As shown in Table 1, there are originally 4 dimensions in this model: "Small vs. Large Power Distance"; "Individualism vs. Collectivism", "Masculinity versus Femininity" and "Uncertainty Avoidance". However, 2 dimensions were added by Michael Minkov in 2010 which are "Pragmatic versus Normative" and "Indulgence versus Restraint” (Hofstede, 2018).

Although mainland China, Taiwan and Hong Kong share an ancient history, when it comes to modern times, they are affected marvelously by different factors, thus lead them to different paths: China by Communism, Hong Kong by British culture and Taiwan still largely remain a Confucian society but combined with Taiwan local culture. The following part would focus on the dimensions of power distance, individualism and uncertainty avoidance, as more related to the media context.

The dimension of Power Distance measures how well people in a culture accept inequalities. Table 1 above demonstrates that affected deeply by 
Table 1. Hofstede 6D-model (Hofstede, 2018).

\begin{tabular}{ccccccc}
\hline & $\begin{array}{c}\text { Power } \\
\text { Distance }\end{array}$ & Individualism & Masculinity & $\begin{array}{c}\text { Uncertainty } \\
\text { Avoidance }\end{array}$ & Pragmatism & Indulgence \\
\hline China & 80 & 20 & 66 & 30 & 87 & 24 \\
Hong & 68 & 25 & 57 & 29 & 61 & 14 \\
Kong & & 17 & 45 & 69 & 93 & 49 \\
Taiwan & 58 & & & & & \\
\hline
\end{tabular}

Communism, Mainland China has an obviously higher score (80) than Taiwan (58) and Hong Kong (68). Applying this theory to media context, Chinese media organizations tend to keep a strong hierarchical form. Within organizations, Chinese journalists are more used to obeying instructions from their commanders, while Hong Kong, affected by western culture, tends to have a smaller power distance, thus journalists would dare more to oppose to their editors.

As for the dimension of Individualism vs. Collectivism, measuring whether people in a culture act more for the interests of their groups or for themselves, Taiwan is the most collectivistic one, while Hong Kong is the most individual one and Mainland China is left in the middle. Therefore, it's possible for Taiwan journalists to have a stronger loyalty to their organizations and choose topics in consistence with the political side of their organizations, while Hong Kong journalists and media organizations may enjoy more diversity. Such a result in Taiwan could to some degree be considered as an effect of Confucianism, which emphasis the strengths of kinship ties and encourage people to maintain strong ties to their ancestors (Weber, 1951). In this way people are not living by individuals but living in groups, if not physically then at least psychologically connected.

When it comes to the dimension of Uncertainty Avoidance, which measures how a society deals with the fact that the future can never be known: should one try to control the future or just let it happen? As shown in Table 1, while Mainland China and Hong Kong has quite low scores ( $30 \& 29$ ), Taiwan's score (69) is considerably high. This indicates that Mainland China and Hong Kong people are more comfortable with ambiguity, thus their news stories could be more ambiguous and their media organizations more adaptable. A possible reason might be that Mainland China and Hong Kong are both used to be imposed with a foreign culture, China by Communism, an ideology born in German, while Hong Kong by western culture brought by Britain. Former beliefs and rituals broken down, people in these two societies may consequently have learnt to adapt to different situations and accept ambiguity.

\section{Social Level: Political and Economic Approaches}

After a story get passed by a media organization to publish, then possible conflicts would take place between the organization and external forces, such as governments, advertisers or the public. 
Many studies have done on this level, usually via political and economic approaches. On a political dimension, Chinese media are commonly described to be concerned with propaganda (Brady, 2008). Organizations act like mouthpieces for the central government which commands communication (Wu, 1994) and journalists are trained as party propagandists (Pan, 2000). Given such a tradition, when it comes comparative studies concerning mainland China, recent researches tend to directly distinguish it with other regions via political forces. For instance, researches may take Taiwan as a society with young liberal democracy, Hong Kong as with partial democracy and China as a one-party state (Chen, et al., 2016).

On an economic dimension, some scholars tend to consider the Party's strict control has been shaken with recognition of market needs by the press under economic reforms since late 1970s (Luther \& Zhou, 2005). After those reforms, media turn to commercial sources for funding, in this way marketization may lead to less forces from the party (Jiang, 2007). However, will marketization certainly lead to conflicts with the party? It is found that journalists in both Shenzhen and Shanghai work with little difficulty in dealing with both the party and the market (Lee, He, \& Huang, 2006). How is that possible?

On one hand, Chinese society is complicatedly riven by deep social chasms, both geographically and vertically (Sparks, 2012). On the other hand, political and economic dimensions are in their nature different. When claiming a change on economic dimension would certainly result in changes on political dimension, one has unconsciously taken the premise of "the economic base determines the superstructure", a point raised by Marx. Agreeing on it or not, before jumping to the conclusion, the premise should be detected and discussed.

\section{Linking Three Levels}

Obviously, whenever a discussion concerns the media system in China, the political dimension is what one should not ignore and remains the most significant factor for Chinese media's uniqueness. However, as Foucault (1990) once mentioned on bio-power, power in modern systems works differently from it was in ancient times. It's no longer working against people but working through them. Consequently, besides the discussion of the power itself, how could certain power work through has become an important issue. According to journalism field, if the political and economic forces on societal level represent a general power, then how could it work through an organization and through each and every individual would require academic attention as well. This essay proposes that such power would work through organizations via culture and through individuals via psychological cultivation. In this way, these three levels could work together and thus ensure the running of an existing system.

\section{Discussions for Further Studies}

The point has actually been made by John Dewey decades ago: "The serious 
threat to our democracy is not the existence of foreign totalitarian states. It is the existence within our own personal attitudes and within our own institutions of conditions which have given a victory to external authority, discipline, uniformity and dependence upon the leader in foreign countries. The battlefield is also accordingly here-within ourselves and our institutions." (Dewey, 1939). Although made decades ago, when it comes to China, this point is still very insightful, especially when compared to Hong Kong and Taiwan.

For journalists, the real battle is not just about breaking free from external political or economic forces, but also about breaking free from internal forces, about dealing with psychological and cultural forces working through them unconsciously every day.

These three societies obviously share different political backgrounds, but such a political difference should not be used as a master key to solve every case regarding these regions. It is possible that the political difference is just a tip of the ice berg while more decisive forces being far deeper down. Besides political and economic forces on social level, there are forces on not only personal level but also organizational level, which could be further examined via psychological and cultural approaches.

\section{References}

Chen, H., Chan, M., \& Lee, F. (2016). Social Media Use and Democratic Engagement: A Comparative Study of Hong Kong, Taiwan, and China. Chinese Journal of Communication, 9, 348-366. https://doi.org/10.1080/17544750.2016.1210182

Dewey, J. (1939) Freedom and Culture (1st ed., p. 49). New York: Capricorn Books.

Du, Y., \& Cheng, B. (2013). Framing the 2011 Egyptian Revolution within Ideological Boundaries: One Incident, Three Societies. International Communication Research Journal, 48, 27-51.

Fang, T. (2003). A Critique of Hofstede's Fifth National Culture Dimension. International Journal of Cross Cultural Management: CCM, 3, 347-368.

https://doi.org/10.1177/1470595803003003006

Foucault, M. (1990). The History of Sexuality, Volume 1. New York: Vintage Books.

Fromm, E. (2009). The Fear of Freedom. London: Routledge. (First Published in 1942).

Fu, P. P., Peng, T. K., Kennedy, J. C., \& Yukl, G. (2004). Examining the Preferences of Influence Tactics in Chinese Societies: A Comparison of Chinese Managers in Hong Kong, Taiwan and Mainland China. Organizational Dynamics, 33, 32-46. https://doi.org/10.1016/j.orgdyn.2003.11.003

Hallin, D. C., \& Mancini, P. (2004) Comparing Media Systems: Three Models of Media and Politics. Cambridge: Cambridge University Press. https://doi.org/10.1017/CBO9780511790867

Hofstede, G. (2018). 6-D Model of National Cultures. https://www.hofstede-insights.com/product/compare-countries/

Jiang, S. (2007). Ideological Influences and News Content Variation in Chinese Newspapers. Paper Presented at the International Communication Association Convention.

Lee, C. C., He, Z., \& Huang, Y. (2006). “Chinese Party Publicity Inc.” Conglomerated: The Case of the Shenzhen Press Group. Media, Culture and Society, 28, 581-602. 
https://doi.org/10.1177/0163443706065031

Luther, C. A., \& Zhou, X. (2005). Within the Boundaries of Politics: News Framing of SARS in China and the United States. Journalism and Mass Communication Quarterly, 82, 857-872. https://doi.org/10.1177/107769900508200407

O’Connor, F., \& Drury B. (1999). The Female Face in Patriarchy: Oppression as Culture. East Lansing: Michigan State University.

Pan, Z. D. (2000). Improvising Reform Activities: The Changing Reality of Journalistic Practice in China. In C. C. Lee (Ed.), Power, Money, and Media: Communication Patterns and Bureaucratic Control in Cultural China. Evanston, IL: Northwestern University Press.

Preda, O. (2012). Hofstede's Dimensions in Portugal. Romanian Economic and Business Review, 7, 62-69.

Rsf.org. (2017). 2017 World Press Freedom Index. https://rsf.org/en/ranking/2017

Sparks, C. (2012). Beyond Political Communication: Towards a Broader Perspective on the Chinese Press. Chinese Journal of Communication, 5, 61-67. https://doi.org/10.1080/17544750.2011.647746

Weber, M. (1951). The Religion of China: Confucianism and Taoism. New York: Free Press.

Wen, J., \& Hou, P. (2015). Comparative Study on Travel Agency Management System in Mainland China, Hong Kong and Taiwan. American Journal of Industrial and Business Management, 5, 37-43. https://doi.org/10.4236/ajibm.2015.51005

Wu, G. (1994). Command Communication: The Politics of Editorial Formulation in the People's Daily. China Quarterly, 137, 194-211.

https://doi.org/10.1017/S0305741000034111

Yang, J., \& Arant, D. (2014). The Roles and Ethics of Journalism. Journalism \& Mass Communication Educator, 69, 33-48. https://doi.org/10.1177/1077695813513767 